\title{
Anti-proliferation and apoptosis effects of Camellia nitidissima C. W. Chi extract on A549 lung cancer cells
}

\author{
Zhi-hui Zhang ${ }^{1 *}$, Pei Li ${ }^{2}$ \\ ${ }^{1}$ Cancer Center, Integrated Hospital of Traditional Chinese Medicine, Southern Medical University, 510315, ${ }^{2}$ Cancer Center, \\ Nanfang Hospital/The First School of Clinical Medicine, Southern Medical University, 510515, Guangzhou, China
}

*For correspondence: Email: zhangzhihui020@126.com; Tel: +86 020-61650124

\begin{abstract}
Purpose: To investigate the effect of Camellia nitidissima C. W. Chi extract (CNCE) on apoptosis and proliferation in A549 human lung cancer cells.

Methods: Inverted microscope was used to examine morphological changes in A549 cells after exposure to CNCE. Trypan blue staining of living cells was applied to construct the cell growth curve after treatment with varying concentrations of CNCE. The influence of CNCE on cell proliferation, apoptosis and cell cycle were determined by MTT assay. The protein expressions of key apoptosisrelated enzymes were evaluated by immuno-cytochemical method.

Results: CNCE inhibited the growth of A549 lung cancer cells at the concentration range of 20 - 160 $\mu \mathrm{g} / \mathrm{mL}$. Flow cytometry showed that CNCE induced apoptosis in the A549 cells. The proportion of cells in G0/G1-phase increased significantly ( $p<0.01)$, while the proportion of cells in S-phase and G2/Mphase decreased correspondingly, indicating that the cells were in G0/G1-phase arrest. Cell cycle arrest and apoptosis-inducing effect gradually increased with increase in CNCE concentration. With increasing concentrations of CNCE, there were significant increases in the expressions of caspase-3 $(p<0.05)$, caspase-8 $(p<0.01)$ and caspase-9 $(p<0.05)$, and significant decreases in Ki-67 $(p<0.01)$ and $p 21$ ras protein $(p<0.01)$.

Conclusion: CNCE exerts significant inhibitory effect on the proliferation of A549 lung cancer cells, and therefore can potentially be developed for the treatment of lung cancer.
\end{abstract}

Keywords: Camellia nitidissima, Antitumor activity, Lung cancer, Apoptosis, Cell cycle arrest, Caspase

This is an Open Access article that uses a funding model which does not charge readers or their institutions for access and distributed under the terms of the Creative Commons Attribution License (http://creativecommons.org/licenses/by/4.0) and the Budapest Open Access Initiative (http://www.budapestopenaccessinitiative.org/read), which permit unrestricted use, distribution, and reproduction in any medium, provided the original work is properly credited.

Tropical Journal of Pharmaceutical Research is indexed by Science Citation Index (SciSearch), Scopus, International Pharmaceutical Abstract, Chemical Abstracts, Embase, Index Copernicus, EBSCO, African Index Medicus, JournalSeek, Journal Citation Reports/Science Edition, Directory of Open Access Journals (DOAJ), African Journal Online, Bioline International, Open-J-Gate and Pharmacy Abstracts

\section{INTRODUCTION}

The morbidity and mortality from lung cancer account for $13 \%$ and $19.4 \%$ respectively, worldwide [1]. Lung cancer is classified into small cell lung carcinoma (SCLC) and non-small cell lung carcinoma (NSCLC). The latter (NSCLC) accounts for most (about $80 \%$ ) lung tumors. At present, early-stage NSCLC is treated by surgical intervention, while mid-late NSCLC is treated with radiotherapy and chemotherapy. Although effective for some patients in the short run, radiotherapy and chemotherapy are associated with adverse effects, toxicity, high recurrence of tumor and poor prognosis [2]. Therefore, it is necessary to reduce the side effects of chemotherapy drugs by searching for 
more effective anticancer drugs with lower toxicity. This has been a major challenge to medical science.

Camellia nitidissima C. W. Chi is a very valuable plant in Guangxi of China. Studies have shown that Camellia nitidissima C. W. Chi has antiaging, blood pressure-lowering, hypoglycemic and immunity-enhancing properties [3]. It also has antioxidant activity [4], and exerts cytotoxic effects on various malignant tumors $[5,6]$. This study was carried out to investigate the effect of Camellia nitidissima C. W. Chi extract on proliferation and apoptosis in A549 human lung cancer cells.

\section{EXPERIMENTAL}

\section{Materials}

Human lung cancer cell line (A549) was purchased from the Institute of Basic Medical Sciences, Chinese Academy of Medical Sciences. Camellia nitidissima C. W. Chi was obtained from Guangxi, China. RPMI1640 culture medium was a product of GIBCO Company, USA). Calf serum and phosphate buffer solution (PBS, American hyclone); dimethylthiozol-2-yl2,5-diphenyl tetrazolium bromide (MTT), dimethyl sulfoxide (DMSO), propidium iodide (PI) and trypsin were obtained from Sigma-Aldrich (America). Caspase-3, caspase-8, caspase-9, Ki67 , bcl-2 p21 ras monoclonal antibodies, and SP generic kits were purchased from American NeoMarkers (San Francisco, USA) .

Samples of Camellia nitidissima C. W. Chi were collected from Guiyang City, Guangxi Province, China in September 2016. Taxonomic identification of the plant was done by Professor Ye Hu of Southern Medical University in China. A voucher specimen (no. CNCE 20160912) was deposited in the herbarium of College of Pharmacy, Southern Medical University, China for future reference.

\section{Instrumentation}

The instruments used were 96-well plates (Corning Company, Wuhan, China); automatic $\mathrm{CO}_{2}$ incubator (DuPont Company of America Napoc6100); 450 enzyme standard instrument (American BioRad); inverted microscope (Olympus CX41-32C02, Japan); 4 \% hope blue mother liquor (Japanese BigWood Industrial Co., Ltd.) and LKB- ultrathin sections machine (Sweden). Others were YZ-1450 laminar flow ultranet work station (Suzhou Purification Equipment Company, Suzhou, China); elite flow cytometer (Coulter, USA); blood cell counting plate; vacuum drying oven (DZF-6021 type, Shanghai Fine Macro Experiment Equipment Limited), and ultrasonic cleaner CQ25-12 type (Shanghai Scientz Biotechnology Research Institute).

\section{Preparation of CNCE}

Dry leaves of Camellia nitidissima C. W. Chi (50 g) were ground and extracted three times by refluxing with $95 \%$ ethanol, each time for $2 \mathrm{~h}$. The extracts were pooled and concentrated under reduced pressure to obtain CNCE.

\section{Cell culture}

The A549 cells were cultured in RPMI-1640 medium (Gibco, Rockville, MD) containing $10 \%$ fetal bovine serum (v/v) (FBS; Hyclone, Logan, UT) and $1 \%$ Penicillin Streptomycin $(100 \mathrm{U} / \mathrm{mL}$ and $100 \mu \mathrm{g} / \mathrm{mL}$, respectively) at $37{ }^{\circ} \mathrm{C}$ in a humidified atmosphere containing $5 \% \mathrm{CO}_{2}$, with $0.25 \%$ trypsin digestion batches. The logarithmic phase of the cells were used for the study.

\section{Drug sensitivity test}

Cells at the logarithmic growth phase (in RPMI1640 medium) at a concentration of $1.0 \times$ $10^{5}$ cells $/ \mathrm{mL}$ of cell suspension, were seeded in 48-well plates and cultured at $37^{\circ} \mathrm{C}$ for $24 \mathrm{~h}$, until the cells became adherent. CNCE at different final concentrations $(30,60,120,240 \mu \mathrm{g} / \mathrm{mL})$ were added to different wells, and the wells were for different periods $(24,48$ and $72 \mathrm{~h})$ at $37{ }^{\circ} \mathrm{C}$. A well containing $20 \mu \mathrm{g} / \mathrm{mL}$ cisplatin served as positive control, while another well containing saline in place of CNCE served as negative control.

\section{Cell morphology assay}

A suspension of A549 cells at the logarithmic growth phase in RPMI 164 medium was adjusted to a concentration of $1.0 \times 10^{5}$ cells $/ \mathrm{mL}$ in a 48 well culture plate, and cultured for $24 \mathrm{~h}$ at $37^{\circ} \mathrm{C}$ to achieve adherence. The wells were grouped into two. One group (experimental group) received different concentrations of CNCE (62.5, 125 or $250 \mathrm{ug} / \mathrm{mL}$ ) in the culture medium, while the other group (control group) received $0.04 \%$ DMSO in place of CNCE. The cells were observed under inverted microscope after 24, 48 and $72 \mathrm{~h}$ for changes in cell size, cell membrane and nucleus.

\section{Growth curve and doubling time (TD) of A549 lung cancer cells}

The A549 cells at logarithmic growth phase at a 
concentration of $1 \times 10^{4}$ cells $/ \mathrm{mL}$ were seeded in 24-well plates. One milliliter was taken from each of three wells at the same time point daily, and digested. The number of cells per well was counted using a hemocytometer, and the mean number of cells was determined. Counting was done for 8 days. A growth curve was plotted with mean cell count as vertical axis, and time as horizontal axis. Doubling time (TD) for the human lung cancer A549 cells was calculated using Eq 1.

$T D=t\left\{\log 2 /\left(\log N_{t}-\log N_{o}\right)\right\}$

where $t$ is time interval, while $N_{o}$, and $N_{t}$ are the initial mean count and mean count after time $t$, respectively.

\section{MTT assay}

A suspension of the A549 cells $(0.2 \mathrm{~mL})$ at logarithmic phase was seeded in a 96-well plate with each well containing $5 \times 10^{3}$ cells, and cultured overnight for cell adhesion. In the experimental group, the original culture medium was drained, and replaced with different concentrations of freshly-prepared CNCE (one concentration in 24 wells, and 6 wells per group). The wells of the control group medium contained $0.04 \%$ DMSO, while wells without cells served as blank control.

All wells were incubated for 24, 48, 72 and $96 \mathrm{~h}$ at $37{ }^{\circ} \mathrm{C}$ in a humid atmosphere containing $5 \%$ $\mathrm{CO}_{2}$. The supernatant was discarded, and $20 \mu \mathrm{L}$ of MTT solution ( $5 \mathrm{~g} / \mathrm{L})$ was added to each well and incubated at $37{ }^{\circ} \mathrm{C}$ for $4 \mathrm{~h}$. Then, the supernatant was carefully removed by suction, and $150 \mu \mathrm{L}$ DMSO was added to each well to dissolve the crystals. The absorbance of each solution was read at $490 \mathrm{~nm}$ against blank control, and the results were used for calculating the growth inhibition rate.

\section{FCM assay}

A suspension of 549 human lung cancer cells $\left(5.0 \times 10^{4}\right.$ cells $\left./ \mathrm{mL}\right)$ at logarithmic growth phase was seeded in 24-well plates $(100 \mu \mathrm{L}$ in each well), and cultured in RPMI 1640 medium for 24 $\mathrm{h}$ for adherence. Thereafter, CNCE was added to a final concentration of $40 \mu \mathrm{g} / \mathrm{mL}$. Wells in the control group contained an equivalent volume of normal saline. The plates were cultured at $37{ }^{\circ} \mathrm{C}$ in an atmosphere of $5 \% \mathrm{CO}_{2}$. At 24 and $48 \mathrm{~h}$, the cells in each group were collected (cell number $>1 \times 10^{6}$ ), washed twice in cold PBS $(\mathrm{pH} 7.2$ - 7. 4), and centrifuged at $1000 \mathrm{rpm}$ for 5 min. Then, $1 \mathrm{~mL}$ of cold precipitation PBS $(\mathrm{pH}$
7.2 - 7.4) was added to the cell suspension, followed by $3 \mathrm{~mL}$ of pre-cooled $70 \%$ ethanol.

The cell suspension was kept overnight at $4{ }^{\circ} \mathrm{C}$, and then centrifugal at $1000 \mathrm{rpm}$ for $5 \mathrm{~min}$. The supernatant was discarded; and the cells were washed twice in $1 \mathrm{~mL}$ of cold PBS ( $\mathrm{pH} 7.2$ - 7.4), and centrifuged at $1000 \mathrm{rpm}$ for $5 \mathrm{~min}$. The cell count was adjusted to $1 \times 10^{6} / \mathrm{mL}$, and $200 \mathrm{uL}$ NaseA was added, followed by incubation in a 37 ${ }^{\circ} \mathrm{C}$ water bath for $30 \mathrm{~min}$. lodide $\mathrm{C}$ ingot $(\mathrm{PI})$ staining fluid $800 \mu \mathrm{L}$ was added, mixed and kept at $4{ }^{\circ} \mathrm{C}$ in the dark for $30 \mathrm{~min}$. DNA single parameter analysis was carried out to determine cell distribution and the proportion of cells in G0/D1, S, and G2/M phases, as a function of time. The results were analyzed using Modifit LT software.

\section{Immunocytochemistry staining}

The A549 cells at logarithmic phase were digested with $0.25 \%$ trypsin, and $2 \times 10^{5}$ cells were seeded into a 6-well plate and cultured overnight for cell adhesion. The culture medium was removed, and $3 \mathrm{~mL}$ of CNCE was added to different cells to final concentrations of 30,60 , 120 and $240 \mu \mathrm{g} / \mathrm{mL}$. Each CNCE concentration was replicated in six parallel wells. In the control wells, CNCE was replaced with an equivalent volume of $0.04 \%$ DMSO. The plates were incubated for 24 and $48 \mathrm{~h}$; the glass slides were taken out, dried and fixed with $4 \%$ paraformaldehyde for $10 \mathrm{~min}$ at $4{ }^{\circ} \mathrm{C}$ according to instructions contained in the operation manual of S-P kit. The plates were observed for appearance of clear brown granules which is indicative of positive cells.

The presence of Bcl-2 and p21 ras in cytoplasm is indicative of positive expression; Ki67 tan is indicative of positive expression in the nucleus, caspase- 9 is an index of positive expression in the cytoplasm and the nucleus; while caspase-3 and caspase-8 indicate positive expression in the cytoplasm or cytoplasm and nuclei. They are expressed less in cells without changes in color, or lightly-colored cells. The cells in the CNCE plates and control plates were observed at high magnification $(\times 400)$ in 5 fields, and positive cells were counted and expressed as percentage of the total number of cells.

\section{Statistical analysis}

All data are expressed as mean \pm standard error of mean (SEM), and processed using SPSS 16.0 (SPSS Inc., Illinois, Chicago, USA). They were analyzed by one-way analysis of variance 
(ANOVA) followed by Dunnett's t-test. $P<0.05$ was considered statistically significant.

\section{RESULTS}

\section{Effect of CNCE on proliferation of A549 cells}

CNCE at different doses significantly inhibited the proliferation of A549 cells after $48 \mathrm{~h}$ when compared with control group $(p<0$. 05). The inhibitory effect was dose-dependent. These results are shown in Table 1.

Table 1: Inhibitory effect of CNCE on the proliferation of A549 cells

\begin{tabular}{llcc}
\hline Group & $\begin{array}{l}\text { Dose } \\
(\boldsymbol{\mu} \mathbf{g} / \mathbf{m L})\end{array}$ & $\begin{array}{c}\text { Absorbance } \\
(\mathbf{2 5 0} \mathbf{~ n m})\end{array}$ & $\begin{array}{c}\text { Inhibition } \\
\mathbf{( \% )}\end{array}$ \\
\hline -ve control & - & $0.365 \pm 0.003$ & - \\
+ve control & 20 & $0.047 \pm 0.002^{2}$ & $91.35 \pm 0.19$ \\
CNCE & 30 & $0.189 \pm 0.002^{1}$ & $49.42 \pm 0.22$ \\
& 60 & $0.186 \pm 0.004^{1}$ & $52.16 \pm 0.31$ \\
& 120 & $0.176 \pm 0.001^{2}$ & $53.24 \pm 0.32$ \\
& 240 & $0.128 \pm 0.004^{2}$ & $62.18 \pm 0.20$ \\
\hline
\end{tabular}

$-\mathrm{ve}=$ negative, $-\mathrm{ve}=$ positive, values are mean \pm SEM $(\mathrm{n}=4) ;{ }^{1} p<0.05,{ }^{2} p<0.01$ relative to control

\section{Effect of CNCE on cell morphology}

Under the inverted microscope, the control group of lung cancer A549 cells grew densely, with overlapping clusters, as a long fusiform or polygon, without direction and with clear cellular edges. On the other hand, A549 cells treated with CNCE at concentrations of 10 and $20 \mathrm{ug} / \mathrm{mL}$ showed reduction in number of cells, and no obvious morphological changes. When the concentration of CNCE reached $40 \mathrm{ug} / \mathrm{mL}$, the cell volume shrank, becoming smaller; and the cells were fewer and separated, with many of floating particles in the culture medium. At concentrations of 160 and $320 \mathrm{ug} / \mathrm{mL}$ of CNCE, there were very clear and obvious changes in cell morphology, and evidence of cell disruption and higher cell death.

\section{Growth curve and TD of A549 human lung cancer cells}

The growth curve of A549 cells is shown in Figure 1. Cell proliferation was initially slow within the first 48 hours, but thereafter rose rapidly and peaked after 6 days, followed by a decline on the $7^{\text {th }}$ and $8^{\text {th }}$ days. The value of TD obtained was 20 .

\section{Inhibitory activity of CNCE}

Results from MTT assay showed that CNCE exerted a concentration and time-dependent inhibitory effects on the growth of human lung cancer A549 cells (Table 2). The inhibitory effect was highest at a concentration of $320 \mu \mathrm{g} / \mathrm{mL}$. In addition, for each CNCE concentration, the inhibitory effect increased with time and became maximum at $96 \mathrm{~h}$.

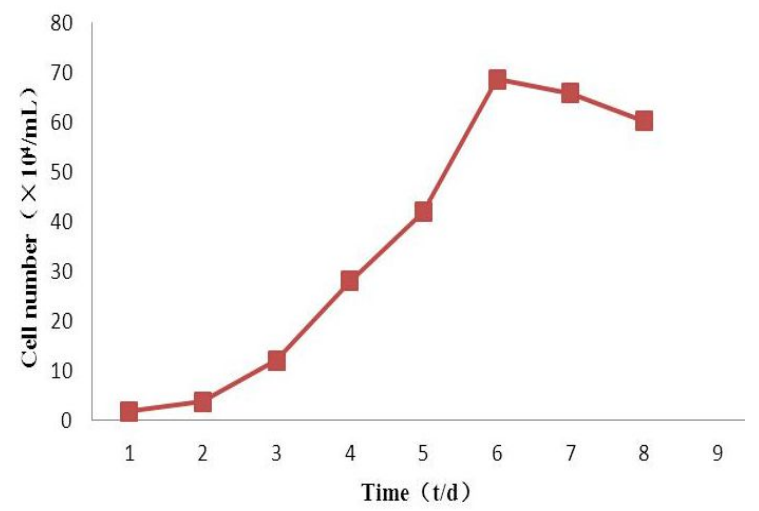

Figure 1: Growth curve of A549 human lung cancer cells

Table 2: Inhibitory effects of CNCE on A549 lung cancer cell growth

\begin{tabular}{llcccc}
\hline Group & $\begin{array}{l}\text { Dose } \\
(\boldsymbol{\mu g} / \mathbf{m L})\end{array}$ & $\mathbf{2 4 h}$ & $\mathbf{4 8 h}$ & $\mathbf{7 2 h}$ & $\mathbf{9 6 h}$ \\
\hline Control & - & - & - & - & - \\
CNCE & 8 & 1.28 & 2.31 & 2.38 & 2.48 \\
CNCE & 16 & 5.36 & 12.34 & 19.37 & 23.31 \\
CNCE & 32 & 24.47 & 27.24 & 35.24 & 41.24 \\
CNCE & 64 & 32.24 & 38.46 & 49.37 & 57.33 \\
CNCE & 128 & 42.12 & 57.14 & 68.37 & 75.46 \\
CNCE & 256 & 43.14 & 58.76 & 70.64 & 78.25 \\
\hline
\end{tabular}

\section{Effect of CNCE on A549 cell apoptosis and cell cycle}

CNCE at a concentration of $40 \mu \mathrm{g} / \mathrm{mL}$ brought about aCNCEst of cell cycle at G0/G1 phase in 24 and $48 \mathrm{~h}$, and blocked the transformation from G1 phase to S phase (Table 3). With increase in G0 - G1 phase transition time, there was reduction in the number of cells in the $S$ phase. The increases in percentage of cells in the G0/G1 phase, and decreases in cells in S phase, were concentration-dependent and timedependent $(p<0.01)$.

Table 3: Effect of CNCE on cell cycle distribution of A549 cells at 24 and $48 \mathrm{~h}$

\begin{tabular}{llll}
\hline Group & G0/G1 (\%) & S (\%) & G2/M (\%) \\
\hline Control & $53.42 \pm 3.87$ & $42.46 \pm 3.34$ & $8.15 \pm 1.07$ \\
CNCE 24 h & $58.35 \pm 3.24^{\star}$ & $35.54 \pm 4.07^{\star}$ & $5.34 \pm 1.46^{\pi}$ \\
CNCE 48 h & $63.75 \pm 4.34^{\star}$ & $23.84 \pm 5.46^{\pi}$ & $3.47 \pm 1.28^{*}$ \\
\hline
\end{tabular}

Values are mean \pm SEM $(n=8) ; p<0.01$ compared to control 


\section{Effect of CNCE on key enzymes of apoptosis and protein expression levels of apoptosis- related genes}

Immunocytochemistry results showed that CNCE at $40 \mathrm{ug} / \mathrm{mL}$ brought about significant increases in the expressions of apoptosis-related proteins caspase- 3 , caspase-8 and caspase- 9 in $24 \mathrm{~h}$, when compared with control $(p<0.01$, Table 4$)$.

Table 4: Effect of CNCE on the expressions of caspase-3, caspase-8 and caspase- 9

\begin{tabular}{lccc}
\hline Group & $\begin{array}{c}\text { Caspase-3 } \\
(\mathbf{\%})\end{array}$ & $\begin{array}{c}\text { Caspase-8 } \\
(\mathbf{\%})\end{array}$ & $\begin{array}{c}\text { Caspase-9 } \\
\mathbf{( \% )}\end{array}$ \\
\hline Control & $16.24 \pm 3.27$ & $18.16 \pm 2.24$ & $27.43 \pm 3.24$ \\
CNCE & $52.34 \pm 4.42$ & $48.62 \pm 4.43$ & $58.43 \pm 5.42$ \\
\hline Values are expressed as & mean \pm SEM; & $p<0.01$ \\
compared with control & &
\end{tabular}

Visible light microscopy showed Ki-67 protein staining in the nucleus; and BCL-2 and p21 ras protein in the cytoplasm. There were more positive cells in the control group, but at a concentration of $40 \mu \mathrm{g} \mathrm{/} \mathrm{mL}$, there were significant decreases in the number of positive cells $(p<0.01)$. The level of protein expression was significantly higher in the CNCE group than in the control group $(p<0.01$, Table 5).

Table 5: Effect of CNCE on the expressions of $\mathrm{Bcl}-2$, $\mathrm{Ki}-67$ and $\mathrm{P} 21$ ras protein

\begin{tabular}{llll}
\hline Group & Bcl-2 (\%) & Ki-67 (\%) & p21 ras (\%) \\
\hline Control & $75.26 \pm 6.45$ & $78.43 \pm 4.98$ & $54.51 \pm 6.12$ \\
CNCE & $43.21 \pm 4.46$ & $39.23 \pm 5.04$ & $28.24 \pm 4.27$ \\
\hline \multicolumn{4}{c}{$P<0.01$ compared with control group }
\end{tabular}

\section{DISCUSSION}

The results obtained in this study show that CNCE has significant time- and concentrationdependent inhibitory effects on the proliferation of A549 cells. The extract also exerted strong apoptotic effects on the A549 cells, as seen from the morphological changes in the cells. The dynamics of tumor cell proliferation are due to loss of control of cell cycle, resulting in uncontrolled G1 / S and G2 / M transformations. The cells were mainly in the active DNA synthesis $S$ phase, which led to abnormal cell proliferation [5]. Thus blockage of the G1/S phase and G2/M phase can effectively control the tumor cell cycle and inhibit tumor proliferation.

In this study, results from cell cycle analysis showed that CNCE reduced the number of A549 human lung cancer cells in $\mathrm{G} 1, \mathrm{~S}$ and $\mathrm{G} 2 / \mathrm{M}$ phases, leading to stagnation of the cell cycle and restraining of cell proliferation. Increased concentrations of aqueous fractions of CNCE brought about enhanced effects on cell cycle aCNCEst. This indicates that CNCE causes lung cancer cell cycle aCNCEst by regulation and inhibition of tumor cell mitosis.

Ki-67 antigen is a more positive marker of nuclear proliferation, and Ki-67 may be used as a biomarker for determining high risk individuals in pre-cancer population [7-9]. Results from Ki-67 antigen assay showed that CNCE significantly decreased the expression of Ki-67 in A549 cells. This implies that a large number of the A549 cancer cells were in the stationary phase of cell cycle. In effect, CNCE may contain active principles that regulate the gene which inhibits cancer cell mitosis, thereby inhibiting the growth of tumor cells.

P21 ras cancer gene is involved in transmission of intracellular information which regulates the cell cycle, and it is the "initiation factor" in the occuCNCEnce of tumors [10-13]. The expression of p21ras antigen was also significantly decreased in the CNCE-treated A549 cells, in a time- and concentration-dependent manner, when compared with untreated controls. Again, this is an indication that most of the cancer cells were in the $\mathrm{S}$ phase of the cell proliferation cycle. This supports the presence of anti-proliferative and mitosis-inhibiting agents in CNCE.

Caspases are proteolytic enzymes which constitute key components of the apoptosis system. They are a family of cysteine proteases involved in regulation of apoptosis, which is considered to be a key to cancer cell death [1417]. In this study, CNCE treatment led to significantly lowered expression of $\mathrm{Bcl}-2$, and significant increases in the expression of caspase-9. These results demonstrate that the anti-proliferative effects CNCE also involve the mitochondrial apoptotic pathway.

Caspase-3 is a pro-apoptosis caspase. Its expression in the CNCE-treated A549 human lung cancer cells was significantly higher than in the untreated control cells, indicating that CNCE promotes apoptosis in these cells. Thus, CNCE induced apoptosis by inhibiting the signal transduction pathway enzymes to achieve elevated expressions of the pro-apoptosis caspases 3, 8 and 9; as well as the apoptosisrelated gene $\mathrm{Bcl}-2$.

\section{CONCLUSION}

The findings of this study reveal that CNCE has significant effect on the inhibition of proliferation and induction of apoptosis in human lung cancer 
A549 cells. These findings suggest that the plant material might be a potent source of drugs for the treatment of lung cancer patients.

\section{DECLARATIONS}

\section{Acknowledgement}

The authors thank Professor Ping Wang, Department of Pharmacy of Zhongshan University for his assistance with data analysis.

\section{Conflict of interest}

The authors declare that there is no conflict of interest associated with this work.

\section{Contribution of authors}

We declare that this work was done by the authors named in this article and all liabilities pertaining to claims relating to the content of this article will be borne by the authors. Zhi-hui Zhang designed all the experiment and revised the paper. Pei Li performed the experiment and wrote the manuscript.

\section{REFERENCES}

1. Wagland R, Brindle L, Ewings $S$, James E, Moore $M$, Rivas C. Promoting help-seeking in response to symptoms amongst primary care patients at high risk of lung cancer. A mixed method study. PLoS One 2016; 11: e0165677.

2. Biaoxue R, Hua L, Wenlong G, Shuanying Y. Increased serum amyloid $A$ as potential diagnostic marker for lung cancer: A meta-analysis based on nine studies. BMC Cancer 2016; 16: 836-838.

3. Amoori N, Mirzaei M, Cheraghi M. Incidence of cancers in Kuzestan province of Iran: Trend from 2004 to 2008. Asian Pac J Cancer Prev 2014; 15: 8345-8349.

4. Bunn Jr PA, Thatcher N. Systemic treatment for advanced (stage IIIb/IV) non-small cell lung cancer: more treatment options; more things to consider. Conclusion. Oncologist 2008; 37: 46-48.

5. Thorn CF, Oshiro C, Marsh S, Hernandez-Boussard T, McLeod H, Klein TE, Altman RB. Doxorubicin pathways: pharmacodynamics and adverse effects. Pharmacogenet Genomics 2011; 21: 440-446.

6. Hanusova V, Bousova I, Skalova L. Possibilities to increase the effectiveness of doxorubicin in cancer cells killing. Drug Metab Rev 2011; 43: 540-557.
7. Kurniawan NA, Chaudhuri PK, Lim CT. Concentric Gel System to Study the Biophysical Role of Matrix Microenvironment on 3D Cell Migration. J Vis Exp 2015; 22: e52735.

8. Alfano $M$, Nebuloni $M$, Allevi $R$, Zerbi $P$, Longhi $E$, Lucianò $R$, Locatelli I. Linearized texture of threedimensional extracellular matrix is mandatory for bladder cancer cell invasion. Sci Rep 2016; 6: 3612836130.

9. Liu D, Guo H, Li Y, Xu X, Yang K, Bai Y. Association between polymorphisms in the promoter regions of matrix metalloproteinases (MMPs) and risk of cancer metastasis: A meta-analysis. PLoS One 2012; 7: e31251.

10. Huang TH, Chiu YH, Chan YL, Chiu YH, Wang H, Huang KC. Prophylactic administration of fucoidan represses cancer metastasis by inhibiting vascular endothelial growth factor (VEGF) and matrix metalloproteinases (MMPs) in lewis tumor-bearing mice. Mar Drugs 2015; 13: $1882-1900$.

11. Hassan ZK, Elamin MH, Daghestani MH, Omer SA, AlOlayan EM, Elobeid MA.Oleuropein induces antimetastatic effects in breast cancer. Asian Pac J Cancer Prev 2012; 13: 4555-4559.

12. Ma $H$, Liu B, Feng $D$, Xie $H$, Li R, Yuchi Y, Wang $H$, Wang J. Pinus massoniana bark extract selectively induces apoptosis in human hepatoma cells, possibly through caspase-dependent pathways. Int $\mathrm{J}$ Mol Med 2010; 25: 751-759.

13. Cui $Y, X i e ~ H$, Wang J. Potential biomedical properties of Pinus massoniana bark extract. Phytother Res 2005; 19: 34-38.

14. Liu J, Bai J, Jiang G, Li X, Wang J, Wu D, Owusu L, Zhang E. Anti-tumor effect of Pinus massoniana bark proanthocyanidins on ovarian cancer through induction of cell apoptosis and inhibition of cell migration. PLOS One 2015; 10: e0142157.

15. Cai Q, Lin J, Wei L, Zhang L, Wang L, Zhan Y, Zeng J, $X u W$, Shen A. Hedyotis diffusa Willd inhibits colorectal cancer growth in vivo via inhibition of STAT3 signaling pathway. Int J Mol Sci 2012; 13: 6117-6128.

16. Zhang JH, Feng DR, Ma HL, Liu B, Wang HB, Xie $H, L i$ $R D$. Antitumor effects of Pinus massoniana bark extract in murine sarcoma $\mathrm{S} 180$ both in vitro and in vivo. Am J Chin Med 2012; 40: 861-875.

17. Wu DC, Li S, Yang DQ, Cui YY. Effects of Pinus massoniana bark extract on the adhesion and migration capabilities of HeLa cells. Fitoterapia 2011; 82: 12021205. 